\title{
Synthesis and characterization of sol-gel derived monophasic mullite powder
}

\section{(Síntese e caracterização de pó de mulita monofásico derivado de sol-gel)}

\author{
A. Jana ${ }^{1}$, D. Ray ${ }^{2 *}$ \\ ${ }^{1}$ Indian Institute of Science, Department of Materials Engineering, CV Raman Rd., Bengaluru, \\ Karnataka-560012, India \\ ${ }^{2}$ University of Calcutta, Department of Chemical Technology, Kolkata, 700009, West Bengal, India
}

\begin{abstract}
High-purity microfine mullite precursor powder of stoichiometric chemical composition, $3 \mathrm{Al}_{2} \mathrm{O}_{3} \cdot 2 \mathrm{SiO}_{2}$, was synthesized through the sol-gel route using aluminum isopropoxide and tetraethyl orthosilicate. The derived mullite precursor powder was characterized by BET surface area, particle size distribution, Fourier-transform infrared spectroscopy, thermogravimetry-differential thermal analysis (TG-DTA), X-ray diffraction (XRD), scanning electron microscopy (SEM), and energy-dispersive X-ray spectroscopy. Phase analysis of the precursor powder and calcined samples at different temperatures was done by XRD. Non-isothermal crystallization kinetics of mullite precursor was studied by TG-DTA in static air using heating rates of 5.0, 7.5, 10.0, 12.5, and $15 \mathrm{~K}$.min ${ }^{-1}$. Grain morphology was studied by SEM. The results showed that synthesized mullite precursor powder possessed homogeneity of Al and $\mathrm{Si}$ components, and the amorphous precursor powder was converted to monophasic mullite crystal when heat-treated at 970 ${ }^{\circ} \mathrm{C}$. Based on Flynn-Wall-Ozawa and Kissinger equations, the activation energy associated with the crystallization of mullite was determined to be 1189.8 and $1189.0 \mathrm{~kJ} \cdot \mathrm{mol}^{-1}$, respectively.
\end{abstract}

Keywords: sol-gel processes, mullite, kinetics, thermal analysis.

\section{Resumo}

Pó precursor de mulita microfina de alta pureza de composição estequiométrica, $3 \mathrm{Al}_{2} \mathrm{O}_{3} .2 \mathrm{SiO}_{2}$, foi sintetizado por rota sol-gel usando isopropóxido de alumínio e tetraetoxissilano. O pó precursor de mulita foi caracterizado por área de superfície BET, distribuição de tamanho de partícula, espectroscopia no infravermelho por transformada de Fourier, termogravimetria-análise térmica diferencial (TG-ATD), difração de raios X (DRX), microscopia eletrônica de varredura (MEV) e espectroscopia de raios $X$ por dispersão de energia. A análise de fase do pó precursor e amostras calcinadas em diferentes temperaturas foi realizada por DRX. A cinética de cristalização não isotérmica do precursor de mulita foi estudada por TG-ATD em ar estático usando taxas de

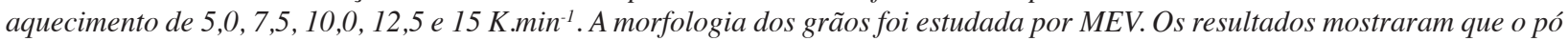
precursor sintetizado de mulita possuía homogeneidade dos componentes Al e Si e o pó precursor amorfo foi convertido em cristal de mulita monofásico quando tratado termicamente a $970^{\circ} \mathrm{C}$. Com base nas equações de Flynn-Wall-Ozawa e Kissinger, a energia de ativação associada à cristalização da mulita foi determinada como 1189,8 e 1189,0 kJ.mol ${ }^{-1}$, respectivamente.

Palavras-chave: processos sol-gel, mulita, cinética, análise térmica.

\section{INTRODUCTION}

Mullite $\left(3 \mathrm{Al}_{2} \mathrm{O}_{3} .2 \mathrm{SiO}_{2}\right)$, the main crystallographic phase in the $\mathrm{Al}_{2} \mathrm{O}_{3}-\mathrm{SiO}_{2}$ system, has appeared as a striking material in the field of ceramics. It exists in a solid solution with composition $\mathrm{Al}_{2}\left(\mathrm{Al}_{2+2 x} \mathrm{Si}_{2-2 x}\right) \mathrm{O}_{10-x} \square_{x}$ having molar ratios of $3 \mathrm{Al}_{2} \mathrm{O}_{3} \cdot 2 \mathrm{SiO}_{2}, 3 \mathrm{Al}_{2} \mathrm{O}_{3} \cdot \mathrm{SiO}_{2}$ and $2 \mathrm{Al}_{2} \mathrm{O}_{3} \cdot \mathrm{SiO}_{2}[1,2]$. Other phases present in this system are corundum, cristobalite, or tridymite and glass. The distribution, nature of the major crystalline phases, i.e., mullite and corundum in the glasses matrix and their relative proportions, are responsible for the development of thermo-mechanical properties of mullite

*drchemtech@caluniv.ac.in

Dhttps://orcid.org/0000-0002-8807-3364 based ceramics. Mullite is an important stable compound found in traditional and advanced ceramics because of its favorable thermal and high-temperature mechanical properties [3]. Its outstanding scientific and technical importance is associated with its high melting point, high thermal stability, low thermal expansion, conductivity, high gas permeability, high creep resistance, and fracture toughness, especially at elevated temperature [4]. Mullite based ceramic is widely used in traditional ceramics such as whitewares, porcelain, structural clay products, and refractories. In addition to traditional ceramics, mullite based ceramic is extensively used as high-temperature engineered material, materials for heat exchangers, structural materials, and optoelectronic material [5]. Mullite is also a promising material for large dimension substrates with high-density electronic packaging because of its thermal expansion 
matching with the silicon chip and low dielectric constant [6]. To make mullite useful for advanced applications, high-purity and lack of glass at the grain boundary are required, and this is only possible if mullite-based ceramic is produced from synthetically prepared starting materials.

Different processing routes for the synthesis of mullite based on different starting materials have been developed which include various methods like solidstate, liquid-state, sol-gel, hydrothermal, chemical vapor deposition, and spray pyrolysis approach though only a few methods have been used by large scale manufacturing industries $[5,7]$. The purity, homogeneity, crystallization temperature, densification, and properties of mullite are highly dependent on the synthesis method. The sol-gel process was widely used because it produces materials with high-purity and homogeneity and is versatile and has good reproducibility [8]. The sol-gel method is based on inorganic polymerization reactions where the starting materials are dissolved in a suitable solvent, and hydrolysis followed by condensation reaction is catalyzed by the presence of an acid or base [9]. This method plays an important role in synthesizing high-purity mullite precursor material for high technological applications. The temperature requirement, activation energy requirement, and the mechanism by which high-purity mullite powder formed from the precursor when heated at elevated temperature strongly depend on the homogeneity of the gels. Depending on the starting materials and their homogeneity level in the gel, two types of mullite precursors can be prepared. One type is designated as monophasic, where the amorphous precursor material is directly converted to mullite at a temperature as low as $980{ }^{\circ} \mathrm{C}[10,11]$, while the other type shows mullitization temperature above $1200{ }^{\circ} \mathrm{C}$ and is named as diphasic [12, 13].

Mullite crystallization kinetics has been reported by many researchers using a different type of starting materials and different thermal methods [14-30]. The most widely used starting material combinations for the synthesis of high-purity mullite precursor using the sol-gel methods are tetraethyl orthosilicate (TEOS) and aluminum tri-sec-butoxide [31], aluminum nitrate nonahydrate (ANN) and TEOS, or aluminum isopropoxide (AIP), ANN, and TEOS [14, 16, 18, 32], and differential thermal analysis (DTA) technique is the extensively used thermal method to study the crystallization kinetics of mullite. Nevertheless, crystallization kinetics has yet to be revealed for monophasic mullite prepared through AIP and TEOS. Considering the potential application of mullite-based ceramic as an advanced material, an attempt has been made to synthesize the high-purity, monophasic mullite precursor powder by the sol-gel route using AIP and TEOS. TEOS is used as a silica source because it is cheaper than colloidal silica. The synthesized mullite precursor was thoroughly characterized, and also effort has been given to reveal the crystallization kinetic by the non-isothermal method.

\section{EXPERIMENTAL}

Preparation of mullite precursor powder: the raw materials used to synthesize the mullite precursor were analytical reagent grade aluminum isopropoxide (AIP, assay 98\%, Aldrich) and tetraethyl orthosilicate (TEOS, assay 99\%, Aldrich). The process of preparation for stoichiometric mullite consisted of thorough mixing of the requisite proportion of TEOS and AIP into 2-propanol at $60^{\circ} \mathrm{C}$ using a magnetic stirrer. The alkoxides in sol were mixed with a solution of water in isopropanol at $60{ }^{\circ} \mathrm{C}$ where both materials were simultaneously hydrolyzed. After 24 $\mathrm{h}$ of vigorous stirring, the gel was dried in a vacuum dryer at $70{ }^{\circ} \mathrm{C}$ for $48 \mathrm{~h}$. Then the vacuum dried material was ground and stored in an incubator for further study.

Characterization of mullite precursor powder: the prepared powder sample of mullite precursor was first ground to fine powder, then thoroughly dried in an air oven at $110{ }^{\circ} \mathrm{C}$ and stored in an incubator maintained at $35 \pm 1{ }^{\circ} \mathrm{C}$. A Strohlein Area Meter II apparatus was used to determine its specific surface area from low-temperature nitrogen adsorption data and the BET principle. The particle size distribution was measured with a Malvern Zetasizer instrument (ZEN1600) in a size range of 0.06 to $6.0 \mu \mathrm{m}$. An FTIR (Fourier-transform infrared) absorption spectrum of the mullite precursor powder sample was recorded by a Perkin Elmer 783 spectrometer in the $\mathrm{KBr}$ phase over the 400 to $4000 \mathrm{~cm}^{-1}$ wavenumber range. In order to investigate the effect of heat-treatment, the precursor was heated at $800,1000,1400$ and $1600{ }^{\circ} \mathrm{C}$ and the identification of material's crystalline phases was carried out in a Philips automatic X-ray diffractometer (X'Pert PRO PW-3071) using Ni-filtered $1.5405 \AA \mathrm{CuK} \alpha$ radiation at a scanning rate of $2^{\circ} \cdot \mathrm{min}^{-1}$. The microstructure of the mullite precursor powder was studied by scanning electron microscopy (SEM, FEI, Quanta 200). Elemental analysis of the mullite compact was done by the energy-dispersive X-ray spectroscopy (EDS). Thermal behavior was performed by thermogravimetry-differential thermal analysis (TG-DTA) using a simultaneous thermal analyzer (Netzsch, STA-409). The mullite precursor sample used for thermal analysis was in the form of loose powder, and pure $\alpha$-alumina powder was used as the reference sample. Well-known and widely used kinetic models proposed by Kissinger and Flynn-WallOzawa were used to analyze the DTA data collected from the run at different heating rates $(\beta)$ of 5.0, 7.5, 10, 12.5 and $15.0 \mathrm{~K} \cdot \mathrm{min}^{-1}$ in order to determine the activation energy for crystallization.

\section{RESULTS AND DISCUSSION}

Characterization of the mullite precursor: in this particular process of synthesis by wet interaction technique (sol-gel), impurity contamination was very small, as pure grade chemicals were used. The mixing of the ingredients was at the molecular level, and gelation occurred by the process of hydrolysis, which led to complete separation 
of the dispersion phase. This type of colloidal gel requires equilibrium for proper orientation of the gel structure, and this was manifested by the liberation of the syneresis liquid. To achieve a high degree of mixing, several authors studied that different parameters like the amount of water for hydrolysis, $\mathrm{pH}$, solvent, and temperature have to be carefully controlled. The vacuum drying process was used in order to minimize agglomeration. The texture of the dried powder was soft, fluffy, and white in appearance consisting of fine particles. Dried mullite precursor powder was ground and thoroughly investigated. From Table I, it is evident that the precursor powder was characterized by microfine particles having a specific surface area of $204.8 \mathrm{~m}^{2} / \mathrm{g}$. The particle size distribution of the dried precursor powder is represented in Fig. 1. Synthesized mullite precursor powder consisted of particles of different sizes distributed over a range of 10 to $350 \mu \mathrm{m}$ and $75 \%$ of the particles within 10 to $150 \mu \mathrm{m}$. Particle size analysis showed that the average particle size of the precursor powder was $35.3 \mu \mathrm{m}$.

Table I - Physical characteristics of synthetically prepared mullite precursor sample.

[Tabela I - Características físicas da amostra precursora de mulita preparada.]

\begin{tabular}{cc}
\hline Physical property & Mullite precursor \\
\hline Mean particle size $(\mu \mathrm{m})$ & 35.3 \\
Surface area $\left(\mathrm{m}^{2} \cdot \mathrm{g}^{-1}\right)$ & 204.8 \\
DTA peak $\left({ }^{\circ} \mathrm{C}\right)$ at $10 \mathrm{~K} \cdot \mathrm{min}^{-1}$ & 50 (endo), 200 (endo), \\
heating rate & 450 (exo), 987 (exo) \\
\hline
\end{tabular}

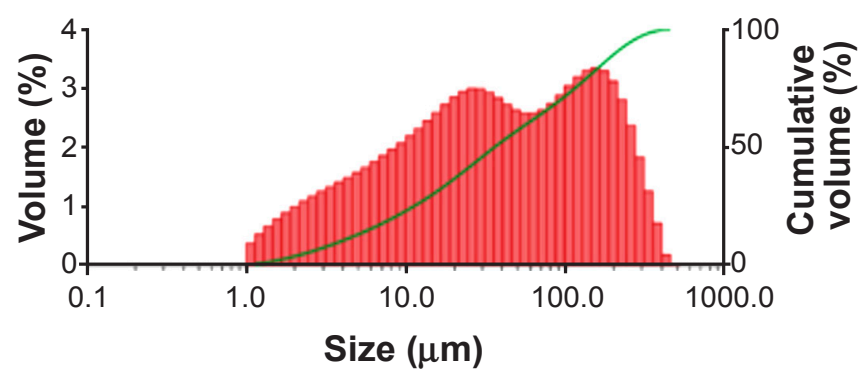

Figure 1: Particle size distribution curves of as-prepared mullite precursor powder.

[Figura 1: Curvas de distribuição granulométrica do pó precursor de mulita preparado.]

FTIR spectrum of mullite precursor gel is shown in Fig. 2. The broad and wide absorption band around 3040 to 3742 $\mathrm{cm}^{-1}$ was associated with the stretching vibration of the $\mathrm{OH}$ group and $\mathrm{H}_{2} \mathrm{O}$ molecule. The absorption region revealed four different bands due to bridging $\mathrm{H}_{2} \mathrm{O}$, bridging $\mathrm{OH}$ group, non-bridging $\mathrm{H}_{2} \mathrm{O}$, and non-bridging $\mathrm{OH}$ groups. The bands at 2988 and $1535 \mathrm{~cm}^{-1}$ could be ascribed to the C-H bending of the alkyl group and $\mathrm{C}-\mathrm{O}$ bonding, respectively, indicating the presence of residual isopropanol, which might not be completely removed during vacuum drying at $70{ }^{\circ} \mathrm{C}$. The absorption bands at 1638 and $1393 \mathrm{~cm}^{-1}$ indicated the bending moment of the free water molecule and organic group, respectively. The presence of an absorption band at around $978 \mathrm{~cm}^{-1}$ was attributed to the $\mathrm{Si}-\mathrm{O}$ stretching vibration mode. The absorption band at $856 \mathrm{~cm}^{-1}$ was assigned to the $\mathrm{Al}-\mathrm{O}$ stretching vibration of $\mathrm{AlO}_{4}$ tetrahedral units. The stretching vibration mode of $\mathrm{Al}-\mathrm{O}$ in aluminum octahedra $\left(\mathrm{AlO}_{6}\right)$ and $\mathrm{O}-\mathrm{Al}-\mathrm{O}$ bending modes of the $\mathrm{AlO}_{4}$ tetrahedral units were observed at $522 \mathrm{~cm}^{-1}$.

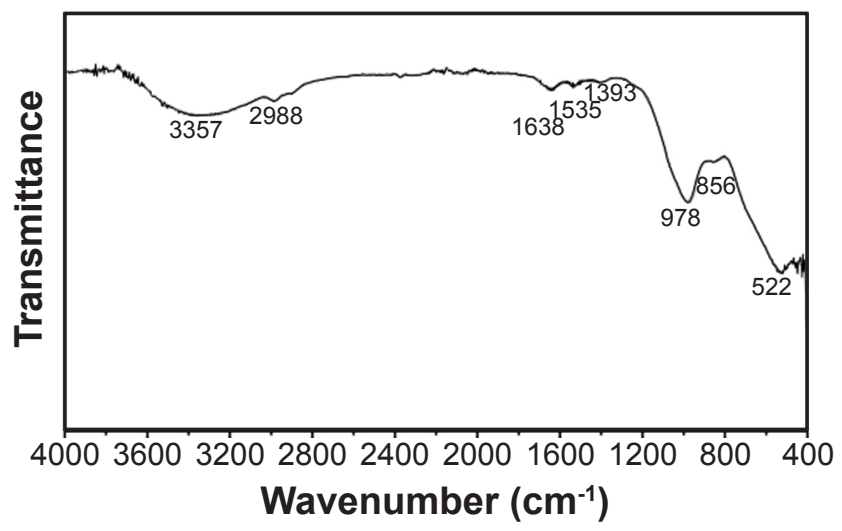

Figure 2: FTIR spectrum of synthesized as-prepared mullite precursor powder.

[Figura 2: Espectro de FTIR do pó precursor de mulita sintetizado.]

TG-DTA curves of the mullite precursor powder obtained in the range of 35 to $1000{ }^{\circ} \mathrm{C}$ with a heating rate of $10{ }^{\circ} \mathrm{C} / \mathrm{min}$ are shown in Fig. 3. DTA curve of the synthetic mullite precursor revealed the existence of two endothermic peaks and two exothermic peaks. The initial endothermic peak in the range of 40 to $65{ }^{\circ} \mathrm{C}$ was associated with the evaporation of solvent from the mullite precursor. The second endothermic peak at about $200{ }^{\circ} \mathrm{C}$ was assigned to the decomposition of hydroxide in the gel. The first broad exothermic peak at about $450{ }^{\circ} \mathrm{C}$ may be due to the overlapping of two effects: the decomposition of the precursor powder and elimination of the organic residue with subsequent burning out. The second exothermic peak at $984{ }^{\circ} \mathrm{C}$ was assigned

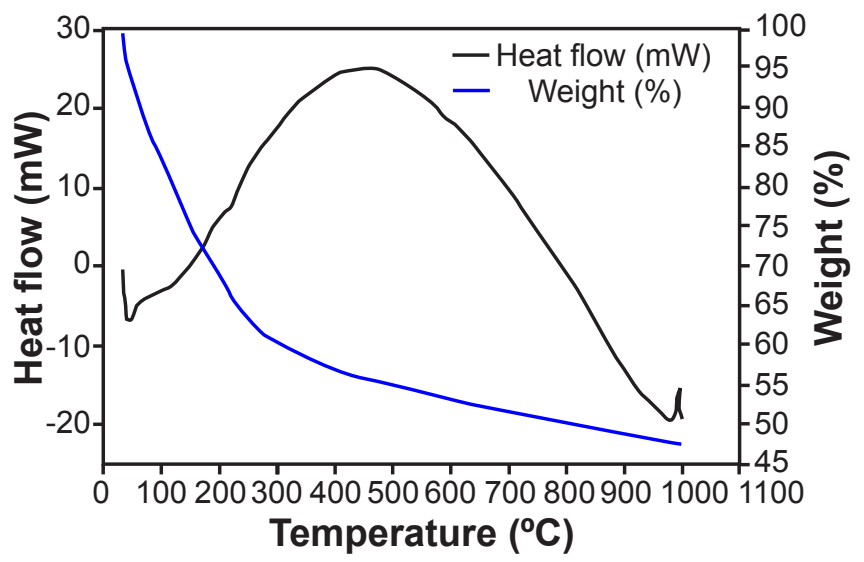

Figure 3: TG-DTA thermograms of as-prepared mullite precursor powder at $10 \mathrm{~K} \cdot \mathrm{min}^{-1}$ heating rate.

[Figura 3: Termogramas de TG-ATD do pó precursor de mulita em taxa de aquecimento de $\left.10 \mathrm{~K} . \mathrm{min}^{-1}.\right]$ 
to the crystallization of mullite. The sharp exothermic peak at $984{ }^{\circ} \mathrm{C}$ indicated a high homogeneity of the $\mathrm{Al}$ and $\mathrm{Si}$ components at the molecular scale, which was beneficial to obtain mullite phase at a relatively low temperature. TG curve of the precursor powder showed a mass loss of around $46 \mathrm{wt} \%$ due to the loss of solvent and removal of a carbon group from the precursor.

X-ray diffraction patterns of mullite (JCPDS 15-0776) precursor powders obtained on heating at 800, 1000, 1400, and $1600{ }^{\circ} \mathrm{C}$ are displayed in Fig. 4. Only the amorphous phase was present when the precursor sample was heattreated at $800{ }^{\circ} \mathrm{C}$. Mullite phase was observed only when the precursor sample was heat-treated at 1000, 1400, and $1600{ }^{\circ} \mathrm{C}$ and confirmed the exothermic peak of mullitization obtained from the TG-DTA analysis. Various researchers established that the crystallization temperature of mullite is an important parameter in the assessment of the degree of mixing of $\mathrm{Al}$ and $\mathrm{Si}$ components in the gels, and the crystallization of mullite depends greatly on the degree of chemical homogeneity. In the present investigation, mullitization occurred at $984{ }^{\circ} \mathrm{C}$, which directly reflected the intensive mixing of AIP and TEOS at a molecular level in the precursor [24] and resulted in very rapid nucleation and short diffusion distances.

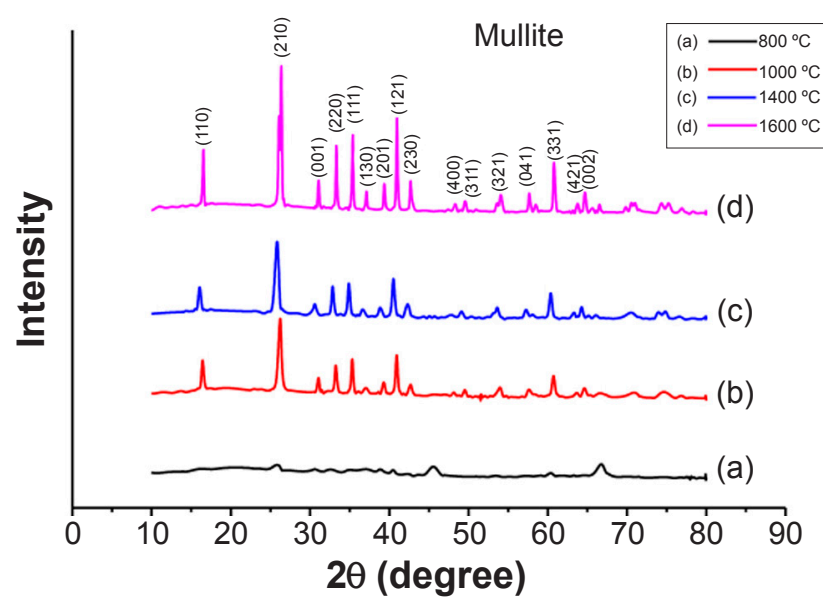

Figure 4: XRD patterns of mullite precursor heat-treated for $2 \mathrm{~h}$ at: a) $800{ }^{\circ} \mathrm{C}$; b) $1000{ }^{\circ} \mathrm{C}$; c) $1400{ }^{\circ} \mathrm{C}$; and d) $1600{ }^{\circ} \mathrm{C}$.

[Figura 4: Padrões de DRX do precursor de mulita tratado termicamente por $2 \mathrm{~h} \mathrm{a}$ : a) $800{ }^{\circ} \mathrm{C}$; b) $1000{ }^{\circ} \mathrm{C}$; c) $1400{ }^{\circ} \mathrm{C}$; e d) $\left.1600{ }^{\circ} \mathrm{C}.\right]$

SEM micrographs of mullite precursor dried at $110{ }^{\circ} \mathrm{C}$, and heat-treated at 1000 and $1600{ }^{\circ} \mathrm{C}$ for $2 \mathrm{~h}$ are shown in Fig. 5. The images showed that morphology of the mullite precursor powder dried at $110{ }^{\circ} \mathrm{C}$ consisted of aggregates of particles, and the regular spherical shaped mullite crystal of 10-20 nm was observed when heat-treated at $1000{ }^{\circ} \mathrm{C}$. On further heating at $1600{ }^{\circ} \mathrm{C}$, mullite crystal grew, lost its spherical shape, and appeared needle-like. In spite of the crystal growth, few spherically shaped mullite crystals were observed, which indicated the requirement of higher temperatures for further growth. Fig. 6 shows the EDS spectrum of mullite powder calcined at $1600{ }^{\circ} \mathrm{C}$ for $2 \mathrm{~h}$,
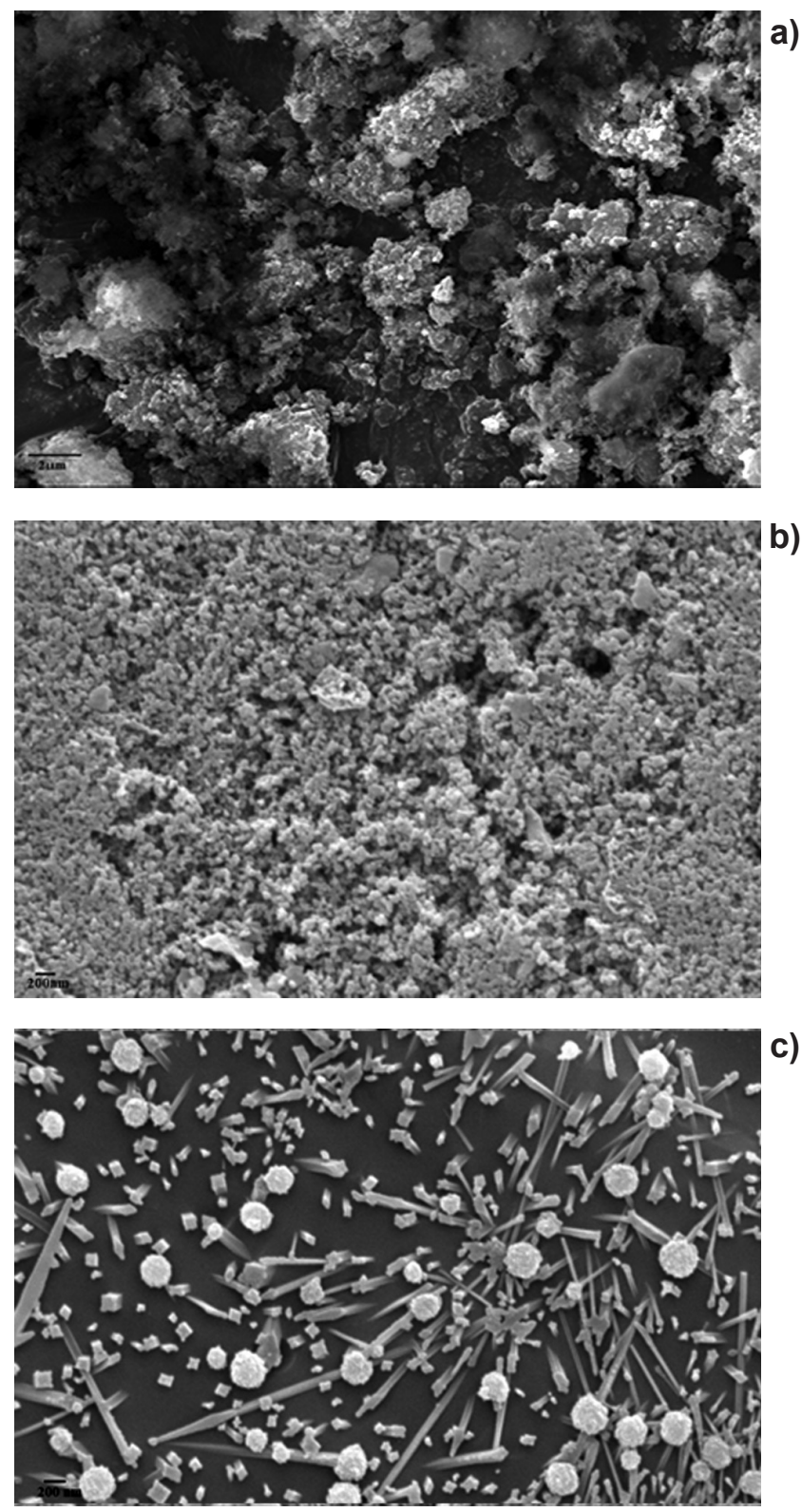

Figure 5: SEM micrographs of mullite precursor dried at $110{ }^{\circ} \mathrm{C}$ (a), and heat-treated at $1000^{\circ} \mathrm{C} \mathrm{(b),} \mathrm{and} 1600^{\circ} \mathrm{C}$ (c) for $2 \mathrm{~h}$.

[Figura 5: Micrografias de MEV do precursor de mulita seco a $110{ }^{\circ} \mathrm{C}$ (a) e tratado termicamente a $1000{ }^{\circ} \mathrm{C}(\mathrm{b})$ e $1600{ }^{\circ} \mathrm{C}$ (c) por $\left.2 \mathrm{~h}.\right]$

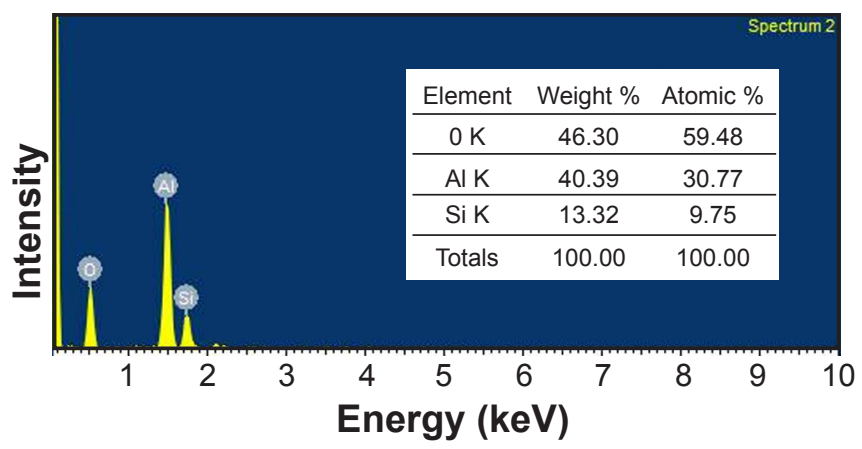

Figure 6: EDS spectrum of mullite precursor heat-treated at $1600{ }^{\circ} \mathrm{C}$ for $2 \mathrm{~h}$.

[Figura 6: Espectro de EDS do precursor de mulita tratado termicamente a $1600^{\circ} \mathrm{C}$ por $2 \mathrm{~h}$.] 
which confirmed that only aluminum, silicon, and oxygen were present in the calcined powder sample and did not contain any impurities. The obtained data showed that $\mathrm{Al}$ and $\mathrm{Si}$ weight ratio was $3.15: 1$ in calcined mullite powder, which is according to its stoichiometry.

Crystallization kinetic study by a non-isothermal method: kinetics of crystallization of synthetic mullite precursor was studied by differential thermal analysis (DTA) in static air using different heating rates under non-isothermal conditions. A non-isothermal method is experimentally easier than an isothermal method, but the accuracy of the activation energy value is generally strongly influenced by experimental conditions such as particle size, particle size distribution, packing, sample size, heating rate, etc. [28, 29]. Fig. 7 shows the DTA curves of the mullite precursor sample in the range of 964 to $1000{ }^{\circ} \mathrm{C}$ at heating rates of $5,7.5$, $10.0,12.5$ and $15.0 \mathrm{~K} . \mathrm{min}^{-1}$ which revealed the existence of an exothermic peak in the range of 970 to $995{ }^{\circ} \mathrm{C}$ corresponding to the crystallization of mullite as confirmed by the XRD analysis of the sample heated at $1000{ }^{\circ} \mathrm{C}$ for 2 h. Mullite crystallization peak temperature shifted towards higher temperature as the heating rate increased from 5 to $15 \mathrm{~K} \cdot \mathrm{min}^{-1}$.

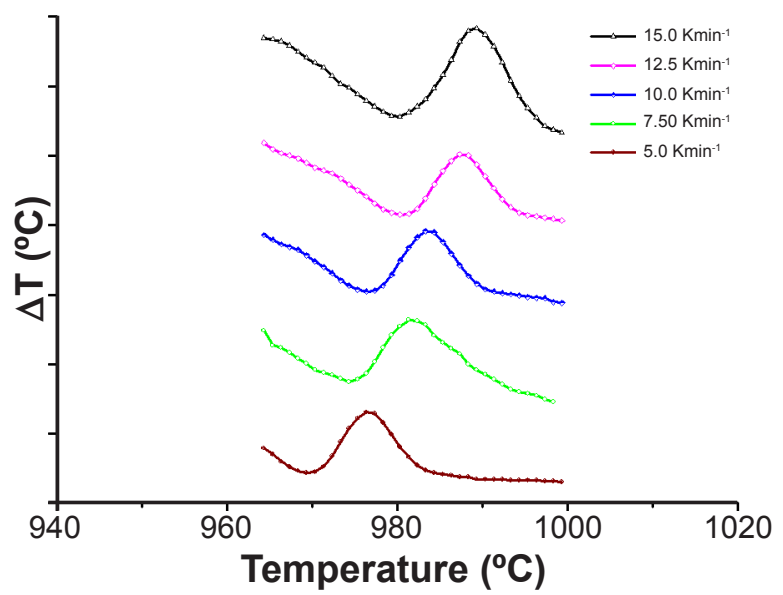

Figure 7: DTA thermograms of as-prepared mullite precursor powder at different heating rates.

[Figura 7: Termogramas de ATD do pó precursor de mulita em diferentes taxas de aquecimento.]

Kissinger [33] and Flynn-Wall-Ozawa [34, 35] equations (Eqs. A and B, respectively) were applied to determine the kinetic parameters of the decomposition process like activation energy and pre-exponential factor.

$$
\begin{aligned}
& \ln \frac{\beta}{T_{\max }^{2}}=-\frac{E_{a}}{R \cdot T_{\max }}+\ln \frac{A \cdot R}{E_{a}} \\
& \log \beta=\log \frac{E_{a}}{R}-\log g(\alpha)-2.315-0.4567 \frac{E_{a}}{R \cdot T}
\end{aligned}
$$

Employing the Kissinger method, a plot of $\ln \left(\beta / \mathrm{T}_{\max }{ }^{2}\right)$ vs. $1 / \mathrm{T}_{\max }$ was drawn by linear regression of the least square method (Fig. 8a). Similarly, on the basis of the Flynn-Wall-
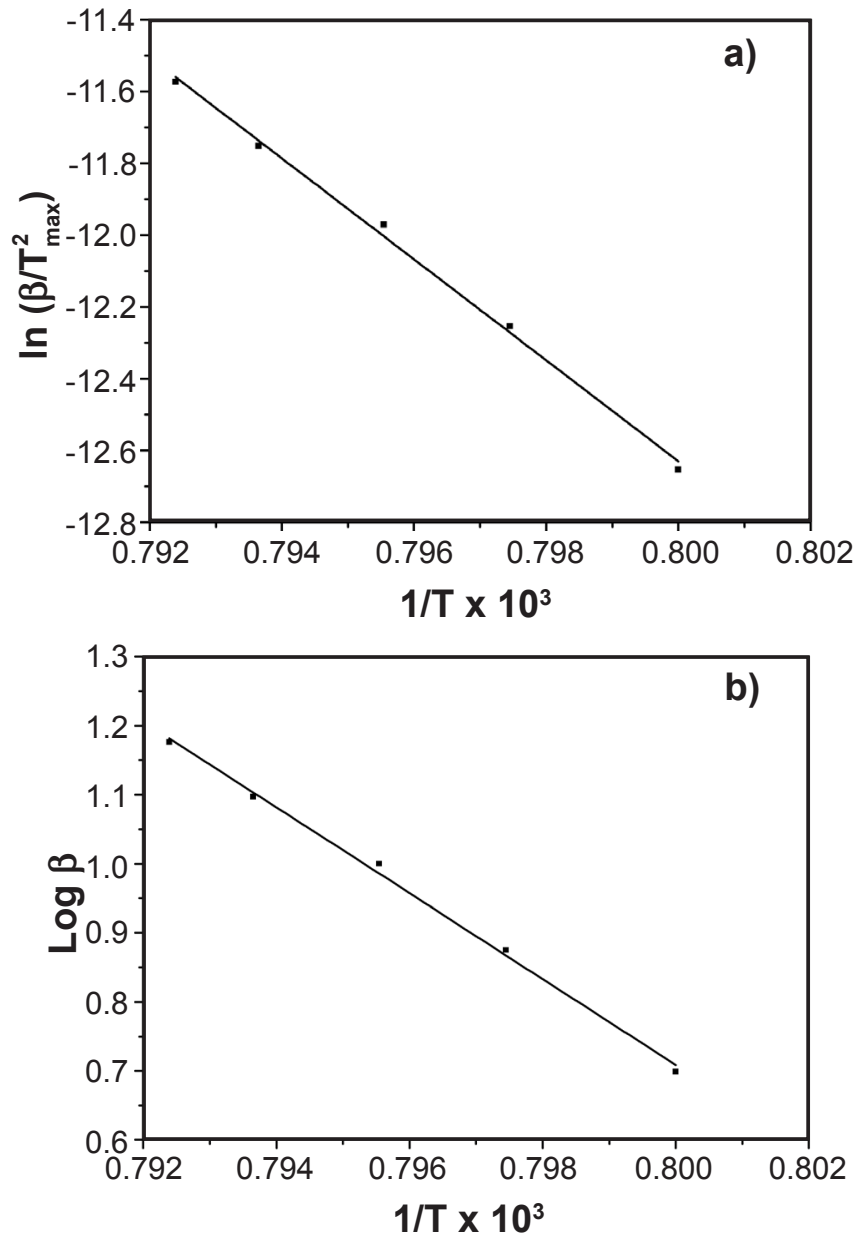

Figure 8: Kissinger (a) and Flynn-Wall-Ozawa (b) plots for the crystallization of the synthetically as-prepared mullite precursor.

[Figura 8: Gráficos de Kissinger (a) e Flynn-Wall-Ozawa (b) para a cristalização do precursor de mulita sintetizado.]

Ozawa method, $\log \beta$ versus $1 / \mathrm{T}_{\max }$ was plotted (Fig. $8 \mathrm{~b}$ ). The activation energy values were calculated from the slope of the straight lines showing striking correlation coefficients $\left(r^{2}\right)$ for both methods (Table II). The activation energy obtained for the crystallization of mullite by Kissinger and Flynn-Wall-Ozawa methods were 1189.0 and 1189.8 $\mathrm{kJ} . \mathrm{mol}^{-1}$, respectively.

The activation energy values for mullite crystallization determined from various starting materials (sol mixtures,

Table II - Activation energy $\left(\mathrm{E}_{\mathrm{a}}\right)$ and correlation coefficient $\left(r^{2}\right)$ for the crystallization of mullite precursor by the nonisothermal method.

[Tabela II - Energia de ativação $\left(E_{a}\right)$ e coeficiente de determinação $\left(r^{2}\right)$ para a cristalização do precursor de mulita pelo método não isotérmico.]

\begin{tabular}{cccc}
\hline Method & $\mathrm{E}_{\mathrm{a}}\left(\mathrm{kJ} \cdot \mathrm{mol}^{-1}\right)$ & $\ln \mathrm{A}$ & $\mathrm{r}^{2}$ \\
\hline Kissinger & 1189.0 & 99.82 & 0.999 \\
FWO & 1189.8 & 50.42 & 0.997 \\
\hline
\end{tabular}

FWO: Flynn-Wall-Ozawa. 
Table III - Activation energy of mullitization reported in the literature.

[Tabela III - Energia de ativação de mulitização relatada na literatura.]

\begin{tabular}{cccc}
\hline Starting materials & Activation energy $\left(\mathrm{kJ} \cdot \mathrm{mol}^{-1}\right)$ & Instrument & Ref. \\
\hline ANN + TEOS & $1053 \pm 51$ & DSC & {$[14]$} \\
Commercial glass fiber & $\sim 1200$ & XRD & {$[15]$} \\
ANN + TEOS & $\sim 1200$ & DTA & {$[16]$} \\
Commercial mullite powder & Step 1: 892; step 2: 1333 & DSC & {$[17]$} \\
ANN + TEOS & $1202 \pm 27$ & DTA & {$[18]$} \\
Aluminum carboxylates + silica sol & 741.4 & DSC & {$[19]$} \\
Pseudoboehmite + TEOS & 1070 & XRD & {$[20]$} \\
Boehmite + TEOS & $1040-1080$ & XRD & {$[21]$} \\
ANN + colloidal silica & 1394 & DTA & {$[22]$} \\
Algerian kaolin & Isothermal: $1290 ;$ non-isothermal: 1260 & DTA & {$[23]$} \\
Kaolin & 1182.3 & DTA & {$[24]$} \\
Fumed silica nanopowder + boehmite sol & $880 \pm 30$ & DTA & {$[25]$} \\
\hline
\end{tabular}

ANN: aluminum nitrate nonahydrate; TEOS: tetraethyl orthosilicate; DSC: differential scanning calorimetry; DTA: differential thermal analysis; $X R D: X$-ray diffraction.

diphasic gels, hybrid gels, monophasic gels, glasses, glass fibers) range from 750 to $1400 \mathrm{~kJ} / \mathrm{mol}$ (Table III) [14-25]. These variations may be related to the variation of starting raw material, presence of impurities, particle size and distribution, specific surface area, processing route, degree of crystallinity, stacking faults, and precise position of $\mathrm{Al}$ and $\mathrm{Si}$ ions in mullite. The activation energy values obtained for the synthetic mullite precursor by Kissinger and FlynnWall-Ozawa methods were consistent with the data reported by Takei et al. [15, 16] and Okada et al. [18] where they had investigated mullite formation process from type I singlephase gels of stoichiometric composition. Others reported activation energy values, which varied from the referred data, are $1053 \mathrm{~kJ} \cdot \mathrm{mol}^{-1}$ [14], $1070 \mathrm{~kJ} \cdot \mathrm{mol}^{-1}$ [20], 1040-1080 $\mathrm{kJ} \cdot \mathrm{mol}^{-1}$ [21], $1394 \mathrm{~kJ} \cdot \mathrm{mol}^{-1}$ [22], $1260 \mathrm{~kJ} \cdot \mathrm{mol}^{-1}$ [23], and $880 \mathrm{~kJ}^{-\mathrm{mol}^{-1}}$ [25]. This variation was originated from the raw material source, type of gel formed, heating rate, and the method used for the kinetic analysis.

\section{CONCLUSIONS}

High-purity mullite precursor was synthesized from an aqueous solution of aluminum isopropoxide (AIP) and tetraethyl orthosilicate (TEOS) by the sol-gel method. The thermal analysis showed that the synthesized mullite powder possessed homogeneity in the mixing scale of the Al-Si components, leading to a sharp exothermic peak at $984{ }^{\circ} \mathrm{C}$ and XRD analysis confirmed the mullitization of the precursor at $1000{ }^{\circ} \mathrm{C}$. EDS result indicated highpurity of the synthesized mullite precursors, which is one the key objective towards the material development for electroceramics application. Crystallization kinetics of monophasic mullite was investigated using nonisothermal conditions. The apparent activation energy values obtained by Kissinger and Flynn-Wall-Ozawa methods were found consistent with each other and with the reported data in the literature.

\section{REFERENCES}

[1] H. Schneider, J. Schreuer, B. Hildmann, J. Eur. Ceram. Soc. 28 (2008) 323.

[2] E.C. Shears, W.A. Archibald, Iron Steel 27 (1954) 26.

[3] L.N.L. Santana, J. Gomes, G.A. Neves, Appl. Clay Sci. 87 (2014) 28.

[4] I.A. Aksay, S.M. Wiederhorn, J. Am. Ceram. Soc. 74, 10 (1991) 2341.

[5] H. Schneider, S. Komarneni (Ed.), "Mullite", Wiley, Germany (2005).

[6] M. Horiuchi, K. Mizushima, Y.Takeuchi,S. Wakabayashi, IEEE Trans. Comp. Hybrids Manuf. Technol. 11 (1988) 439.

[7] H. Schneider, K. Okada, J. Pask, in "Mullite and mullite ceramics", Wiley, New York (1994) 83.

[8] C.J. Brinker, G.W. Scherer (Ed.), "Sol-gel science: the physics and chemistry of sol-gel processing", Acad. Press, San Diego (1990).

[9] D.G. da Silva, W.L. Vasconcelos, Cerâmica 65, 373 (2019) 70.

[10] D.W. Hoffman, R. Roy, S. Kmarneni, J. Am. Ceram. Soc. 67 (1984) 468.

[11] H. Schneider, B. Saruhan, D. Voll, I. Merwin, A. Sebald, J. Eur. Ceram. Soc. 11 (1993) 87.

[12] H. Schneider, M. Schimucker, K. Ikeda, W.A. Kaysser, J. Am. Ceram. Soc. 76 (1993) 2912.

[13] K. Okada, N. Otsuka, J. Am. Ceram. Soc. 69 (1986) 652.

[14] E. Tkalcec, R. Nass, J. Schmauch, H. Schmidt, S. Kaurajica, A. Bezjak, H. Ivankovic, J. Non-Cryst. Solids 223 (1998) 57.

[15] T. Takei, Y. Kameshima, A. Yasumori, K. Okada, J. Am. 
Ceram. Soc. 82 (1999) 2876.

[16] T. Takei, Y. Kameshima, A. Yasumori, K. Okada, J. Eur. Ceram. Soc. 21 (2001) 2487.

[17] B.R. Johnson, W.M. Kriven, J. Schneider, J. Eur. Ceram. Soc. 21 (2001) 2541.

[18] K. Okada, J. Kaneda, Y. Kameshima, A. Yasumori, Mater. Lett. 57 (2003) 3155.

[19] H. Tan, Y. Ding, J. Yang, J. Alloys Compd. 492 (2009) 396.

[20] W.C. Wei, J.W. Halloran, J. Am. Ceram. Soc. 71 (1988) 581.

[21] D.X. Li, W.J. Thomson, J. Am. Ceram. Soc. 73 (1990) 964.

[22] J.E. Lee, J.W. Kim, Y.G. Jung, J.C. Yong, Ceram. Int. 28 (2002) 935.

[23] F. Sahnoune, M. Chegaar, N. Saheb, P. Goeuriot, F. Valdivieso, Adv. Appl. Ceram. 107 (2008) 9.

[24] Y.F. Chena, M.C. Wang, M.H. Hona, J. Eur. Ceram. Soc. 24 (2004) 2389.

[25] A.R. Boccaccini, T.K. Khalil, M. Bucker, Mater. Sci.
Lett. 38 (1999) 116.

[26] J. Leivo, M. Lindén, M. Ritola, M. Vippola, E. Livanen, T.A. Mantyla, Mater. Chem. Phys. 115 (2009) 56.

[27] E. Tkalcec, H. Ivankovic, R. Nass, H. Schmidt, J. Eur. Ceram. Soc. 23 (2003) 1465.

[28] K. Okada, J. Eur. Ceram. Soc. 28, 2 (2008) 377.

[29] A.L. Campos, E.Y. Kawachi, T.C. Oliwera, G. Thim, Mater. Sci. Eng. B 122, 3 (2005) 169.

[30] K. Okada, S. Yasohama, S. Hayashi, A. Hasumori, J. Eur. Ceram. Soc. 18, 13 (1998) 1879.

[31] N.E. Quaranta, E.R. Benavidez, Cerâmica 45, 291 (1999) 38.

[32] S. Ilić, B. Babić, A. Bjelajac, N. Stoimenov, L. Kljajević, M. Pošarac-Marković, B. Matović, Ceram. Int. 46 (2020) 13107.

[33] H.E. Kissinger, J. Res. Natl. Bur. Stand. 57, 4 (1956) 217.

[34] J.H. Flynn, L.A. Wall, A. Quick, J. Polym. Sci. B 4, 5 (1966) 323.

[35] T.J. Ozawa, J. Therm. Anal. Calorim. 2 (1970) 301.

(Rec.06/12/2019, Rev. 18/03/2020, Ac. 07/04/2020) 